\title{
NATURE OF CERTAIN CRIMINAL ACTS AGAINST THE ECONOMY IN THE AREA OF CUSTOMS BY KOSOVO LEGISLATION - PARTICULARLY OVERVIEWED BY MATERIAL TARGET
}

\author{
Bahri Hyseni ${ }^{1}$ \\ ${ }^{1}$ Mr sc. international relationship and Diplomacy sciences -, PHD Candidate in the Criminal Field at University of \\ Tirana, Ramadan Salihu str. no. 68, Ferizaj-Kosovo Po. Code 70000
}

\begin{abstract}
Offenses against the economy in general and in particular those in the customs area pose a risk and challenge not only for economic development but also for the legal system in general. Kosovo, but other countries also in the region, have enacted criminal legislation by European standards, to regulate the customs area as the main contributor to filling the budget. So my goal in this work to analyze this issue will be a material object, of some criminal offenses in the field of economy with emphasis on custom field, provided in the Criminal Code and Code of Customs and Excise tax of Kosovo. Nowadays there is no doubt that this group of offenses, causes a great loss of public revenue to the Kosovo budget in millions of euros, fact which is admitted by the customs service, witch in the regular report of 2006, has determined that due to fraud and other forms of smuggling $20 \%$ of goods are not subject to payment of customs taxes and bring great damage to the national economy. By these criminal acts, there are created illegal material benefits which seriously damage the economy and create informal economy, harm legal competition, raise prices, and as a result of all this, is the damage to the financial system of state and the welfare in general. Within this Target Material will be covered: Smuggling of goods, Evasion of mandatory payments of customs, and fraudulent avoidance of Prohibitions and restrictions on goods. At the end of the work $i$ will analyze measures and penalties that the Kosovo criminal legislation provides, for the perpetrators of these acts.
\end{abstract}

Keywords: Target material, penal code, offenses in customs, smuggling, taxes and scams

\section{DAMAGES IN THE CUSTOMS AREA}

Criminality in the field of customs no matter in which way occurs, presents serious crime. Crimes such as smuggling are widespread and pose great danger to society and state interests. Kosovo and other countries, generate substantial revenues through customs taxes for the budget, in order to ensure the functioning of public institutions and services. Therefore, since the establishment of the Kosovo Customs Service in August the $30^{\text {th }} 1999^{1}$ ( $U N M I K$ Regulation, No. 1999 / 3, 19992.) and until now, Customs is the largest contributor to the budget, and it is a known fact that $70 \%$ of budget revenues of different sorts, are made by the Customs Service. But more important is the fact, that besides the filling of the budget ark, the same budget also has been engaged in the protection of the local economy and combating negative phenomena's. No society, especially societies in transition, are not immune from the financial crimes that harm state budgets and creates insecurity and instability in financial and economic system. Because of fraud's performed in the collection of customs obligations, Kosovo loses millions of euros, which fact has been actually admitted by the Customs Service itself, that $20 \%$ of goods entering Kosovo are not subject to payment of duties $^{2}$. (Annual Report of the Kosovo Customs Service, 2006)
The consequences of this crime cause extremely great harm to the economy, market, conscious importers, that are subject to customs fees, because when introducing goods into Kosovo with deviations from customs, the goods featured in the market is "a commodity from the black market" as defined by the law of the Tax Administration of Kosovo $^{3}$ (See: Law of Tax Administration of Kosovo ) So the imported goods from informal trade, makes an unfair competition to conscious Importers and also reduces the competitiveness of local products that are of domestic manufacturers, because these goods are sold in the market at a cheaper prices. Among the main effects that bring harm to the commercial area, i would distinguish: Creating inequality in the world of business, creating a conviction to wide commercial entities that the law is not functioning, and leading in the direction of the path of illegal tax evasion, creating evasion and illegal profits and creating social inequality. As a result of such condition is expected to arise dozen other negative consequences that endanger public safety and health ${ }^{4}$.(Arben Rakipi, Corruption and tax evasion, Tirana, 2003, p .123) Also are created excess and free cash, where those can be used for bribing customs officials to be performed illegal subsidies. Other caused damages can be also serious social consequences, coming as a result because such businesses can be criminally charged, and their commercial activity would cease, bringing poverty and unemployment, that would bring loss to state coffers budget $^{5}$.( Ibid p. 124). Therefore to get protected from these 
crimes in the area of customs, most countries including Kosovo and Albania has foreseen these acts in their customs laws. In the year of 2004, in Kosovo has been approved a temporary Customs Code of Kosovo, which has replaced the applicable custom law and that: Yugoslavia's Customs Law of 1992 and the Law on Customs offenses by which are violated federal provisions since $1977^{6}$ (Temporary Customs Code of Kosovo of 2004, (Regulation 2004/1). In the Customs code legislator has foreseen 9 offenses dealing with customs officers and persons appearing on the international movement of goods.

Excise Code also, has incriminated criminal offenses in the field of Customs ${ }^{7}$. (See UNMIK Regulation no. 2005/32 ) Given the fact that these offenses in Kosovo, have been frequent after the war and have brought losses to the state budget in millions of euros, in which case from these offenses has resulted expressed tax evasion and poor budget. The state of Kosovo has created adequate legislation in this direction, to protect the economy and the financial system in general. Currently except Customs and Excise code, to this field criminal and legal protection gives the penal code also, that by my opinion, in details has arranged all possible forms of appearance of this crime, beside predicting the prison sentences, has also foreseen confiscation of goods and property that are the source of these offenses.

\section{NATURE OF CERTAIN CRIMINAL OFFENSES IN CUSTOMS AREA, PARTICULARLY OVERVIEWED BY MATERIAL TARGET}

Smuggling is a negative phenomenon with high social risk, which is manifested in different forms, making it as the most organized criminality in the customs area. The beginnings and development of the smuggling of goods are related to the phenomenon of the appearance of national borders, through which were created obstacles to the free circulation of goods $^{8}$. (Vesel Latifi, Criminology, Pristina, 2006, p 189) The nature of target material of these offenses is not only different kinds of goods, but also forms and their smuggling. Material target of these acts are prohibited goods for import and export, especially those specially prohibited by law. So the target study of these criminal offenses are the goods, that if any trade is made with them, it should be taken prior permission license from the competent authority ${ }^{9}$. (Ismet Salihu, Criminal Law, Special Part, 209, p 373)

Prohibited goods for import and export by the Customs Code in Albania are: poisonous substances, infected plants and animals, weapons of all kinds, copper scarab waste, aluminum, lead, and other precious metals ${ }^{\mathbf{1 0}}$. (Ismet Elezi Criminal Law CC), Tirana, 2009, p. 287From what we saw, overall target study of these criminal offenses in the area of customs, are legal relationships established for normal functioning of the customs of the Republic of Kosovo. The purpose is the protection of the economic interests from any illegal activity aimed to avoid payment of taxes and mandatory contributions to the state budget. Comparing our legislation with the Republic of Albania, it is noticed a unification that legal provisions have, in determining the nature of the material target and the forms of it's appearance. In the following we will discuss some of the offenses in the customs area.

\subsection{Smuggling of Goods (Article 317)}

Criminal offenses "Smuggling of goods" is incriminated in the penal code of 2012, in the group of offenses in the field of economy, unlike the criminal code of 2004 that has incriminated this in the group of offenses against property. By this offense we mean; whoever carries goods crossing the border line and avoid customs control, or whoever avoiding customs control, performs the transfer of goods and crosses the border line. Goods which are subject to the criminal offense of smuggling are goods which are prohibited to be imported, or their transfer has restrictions. Also smuggling is carried out, by illegal acts of persons, who without a permit or license carry goods, for which the state has set high taxes, like excise-goods (tobacco, cigarettes, coffee, alcoholic beverages, fuel, etc). So this Criminal offense is committed intentionally by a person who without authorization carries goods outside the state border, outside the official crossings. We have incriminating action even when the border is crossed legitimately, but the merchandise is't not reported to customs control, but in such case it is more the matter of customs misdemeanor or criminal offense of tax evasion.

Material target of this offense are prohibited goods for import and export, and all goods entering illegally in Kosovo outside the official border, crossing, in order to avoid the payment of customs excise respectively. The Criminal Code of Kosovo has strictly sanctioned this act, taking into account that these acts form the basis of international organized crime. So that goods like narcotics, stolen vehicles illegally cross state borders, then being provided with false documentation, customs fictitious invoices to conceal the origin of the goods ${ }^{11}$. ( Franjo Bacic, and Pavlovic Shima, Penalty Law, special part, Zagreb 2001, p. 368 ). This criminal offense is connected with money laundering and organized crime. In Article 317, paragraph 3 penal code has provided a qualified manner of performing this criminal offense in section 3.1, 3.2, and 3.3, where is foreseen that if the perpetrator crosses the border, with goods or hazardous substances, which putt's the people's lives and health in to a risk, or present a risk to the overall security, or perpetrator uses force and dangerous tools during the commission of the offense, shall be punished with imprisonment of (1) through (10) years, and paragraph 4 provides that the goods to be confiscated ${ }^{12}$ (See Criminal Code of Kosovo of 20 012, Article 313, paragraph 3 and 4 ). This criminal act is extremely present in Kosovo, in other Balkan countries and the European Union. Kosovo Custom's statistics show that only smuggling of cigarettes has caused to the budget a loss of millions of euros ${ }^{13}$ (See Annual Reports of the Customs Service from 2005 until now ). That the smuggling of goods is widespread in European Union countries, especially those of cigarettes, speaks the fact that the German state had initiated investigations in 
2005, where i considered that the actual material damage to the European Union was caused up to (10) billion euros ${ }^{14}$ (See Kosova Sot newspaper dated March 8, 2006, no. 2316). Incrimination of this criminal offense has foreseen the Albanian Criminal Code in force unlike that of 1977, by which was foreseen only one criminal provision, where now by this code it's given to it a more effective criminal-legal defense, because there are nine criminal provisions, foreseen for various types of smuggling. Foreseen penalties are also very strict, and they go to (10) years imprisonment and smuggled goods are confiscated. Finally I think that the current legislation in power in Kosovo and Albania is by the standard's of European Union Legislation, and is a good prevention to preserve the country's economy from these criminal acts, that cross state borders and pose great risk of tax evasion and impoverishment of the ark of the state budget.

\subsection{Avoiding the Compulsory Payment of Customs}

\section{Tariffs (Article 318)}

The most spotted problems in the issue of economic development of the country, remains the challenge facing the criminal offenses related to tax evasion in the field of economy. In modern society the growth of criminal offenses in the field of customs, it's considered an obstacle in economic development, economic order and the legal system in general. Kosovo as an independent state has issued criminal legislation based on European standards, to regulate the customs field as an important and most contributing institution of filling the budget of Kosovo. Criminal act of, avoidance of payment of customs tariffs, is the most frequent act which has dominated, regions across the territory of Kosovo, especially in the post war period, because the emerged institutions, from war, were still lacking in the organizational view, and due to the lack of adequate legal infrastructure to convey these ugly criminal phenomenon. It is worth mentioning that the criminal offense avoidance of compulsory payment of customs tariffs, happen in the case of goods clearance, when importing entities, or other participants in the procedure for application for clearance of goods, tried in various ways to avoid disclosure of the exact terms as far as concern: quantity, value, or quality and origin of goods, so that in the name of importing plates pay the lowest amount of actual base amount, that would pay by the declaration (appearance) of real goods.

Material target of this criminal offence are: certain goods, which are in any way involved in avoiding the payment of customs binding, therefore a crucial element of this act, is the perpetrators subjective attitude to the act, and he did this in order to avoid the payment of duties, by which these goods are charged for. The criminal code, has sanctioned this offense in article 318, in the group of criminal offenses, in the field of economy, where has foreseen that whoever has the intent to enable to himself or to other person, evasion from payment of customs duties, during importation or expertise, presenting false documents concerning the origin, value, quality, quantity, type, or other characteristics of the goods shall be punished by a fine or imprisonment of up to (3) years. As if the value of avoidance exceeds 15,000 euros, the perpetrator shall be punished by a fine and imprisonment of up to (5) years, whereas when the amount exceeds 30,000 euros, will be punished by fine and imprisonment by (1) through (8) years. Goods that are not declared correctly or the payment of value has been avoided, whichever is higher shall be confiscated ${ }^{15}$. (See Penal Code of 2012, Article 318, paragraph 1-). This act is new and has not been incriminated even in the Provisional Criminal Code of 2004, nor in the criminal law of KSAP of 1977. While this criminal offense has been incriminated in temporary Customs Code of Kosovo, where besides this act, there are also 8 other criminal offenses relating to customs officers, and persons appearing on the international movement of goods $^{16}$. (See: Applicable Law and the Provisional Customs Customs (Regulation 2004/1) Also Customs and Excise Code of Kosovo, has foreseen this criminal offense named "Avoiding fraudulent import and excise taxes." Attempt to commit criminal offense is punishable ${ }^{17}$. (See the Customs and Excise in Kosovo in 2009, neni298). Therefore damages that this criminal offense brings, can be presented as follows: Damage, reduce of budget of Kosovo, disorders in the market economy, loss of product quality, reduce of number of rentable businesses, creating inequality in the market.

Finally I think that to reduce this type of crime, state of Kosovo shall affect in the strengthening of its institutions, and apply those policies, that ensure economic stability and sustainable business, build up criteria's, aiming to build healthy and strong business, and not to those fleeing VAT and other duties prescribed by laws. Thereafter Kosovo's government should prepare in advance a package of favorable measures, for large businesses and inside of it, having mechanisms for the elimination of informality and tax evasion, applying fiscal cash deployment to any business either if it's small or large, that develops economic activity, because by placing cash registers, would be put under proper control and supervision, and so it will made impossible to avoid tax obligations to the state, these revenues that will bring to the Kosovo budget and filling not the contrary emptying of state ark. These and other measures either of the criminal sanctioning character od Administrative ect, are prevention for sustainable security and economic stability.

\subsection{Fraudulent Evasion of Prohibitions and}

\section{Restrictions on Goods}

Under Section 299 of the Customs and Excise this criminal offense means: Anyone who is in any way involved in the fraudulent evasion related to goods, out of any prohibition or restriction on the importation of goods under applicable law. The perpetrator of this crime shall be punished by a fine or imprisonment (3) months to (5) years. Attempt of this criminal offense is punishable ${ }^{19}$. (See Customs and Excise Code of Kosovo, no. 03 | L-109 Article 299). 
Material target of this criminal offence are: legal relationship established by law for the importation of prohibited goods for import. These goods at importation are presented by other names, other tariff number then Authentic one, hiding the origin. Cases that have occurred in practice, during importing of goods in Kosovo customs, are especially pharmaceutical products, when is attempted to enter Viagra by putting those in boxes of vitamins, hiding the contents, origin of goods in order to avoid misleading prohibited or restricted by law, or importation of vehicles older than eight years ${ }^{20}$ (See UNMIK Regulation, 2005/11) To the damage of Kosovo budget, great impact have these criminal offense, to the fact that the border crossings in northern Kosovo, are not placed under the full control of Kosovo customs officials. According to the 2010 annual report of the customs, it is noted that crime has flourished in that part, and this is supported by the following facts: There are submitted 49 criminal charges for possible or confirmed evading, in the amount of 42 million euros, according to the report, there have been 64 cases under investigations, where possible avoidance may be 4 million euros, then have been raided 18 different locations, where has resulted with 4 arrested people, while the value of seized goods. is 868,236.29 euros $^{20}$ (See Annual Report of KC 2010). Criminal Code of Kosovo nor 2004 nor that of 2012 , has not incriminated this criminal offense. This work and several offenses related to various customs fraud, misuse of official position by the officers, Forgery presented documents for customs purposes, are foreseen in the Customs Code as a special law. Finally I think, that the customs code has adjusted in details these acts, with clear specific provisions, adapted to the actions and forms of the offense in practice, unlike the penal code that has, not very specified generalized formulations.

\section{CONCLUSION}

Offenses against the economy with special emphasis, those in the custom field are steadily increasing and represent a huge losses to the Kosovo budget. I think that because the target material of these offenses is specific, it presents difficulties in detecting them, because the perpetrators of these acts, are often customs officials themselves, who are called by law to stop fraud and avoidance of customs duties. By treating the target material of criminal offenses "Smuggling of goods" and "Fraudulent Evasion of customs duties", we can conclude, that the inefficiency of state bodies, in the fight against these crimes, creates economic instability, unfair competition, informal economy and depletion of the budget. Therefore the state of Kosovo must continuously monitors the development of the customs and economic crime, in order to create legislation that will be pre acting and not behind acting, in relation of trends development of this crime. I believe that the State of Kosovo must take specific steps to strengthen all the border points in northern part, and to be stopped entry of the goods without paying customs duties.

Kosovo needs deep reforms in the customs service authorities and judicial bodies, to specialize public administration officials, in the field of criminal offenses against the economy and customs, that in cooperation with prosecuting authorities, successfully fight this potential crime.

I finally think, that the official data that the justice authorities possess, for the number of criminal offenses in the economy with emphasis on custom field, are not realistic, in relation to acts that are committed in practice, but unfortunately they remain undiscovered.

\section{REFERENCES}

[1] Arben Rakipi, corruption and tax evasion, Tirana 2003

[2] Franjo Bacic, and Pavlovic Shima, Penalty Law, Special Part, Zagreb 2001

[3] Vesel Latifi, Criminology, Pristina, 2006

[4] Ismet Elezi, "The Criminal Law (CC), Tirana, 2009

[5] Ismet Salihu, "Criminal Law" (the special), Pristina, 2009.

[6] Suceska M., "Fundamentals of Economic Crime", Pristina, 2006, KSF, 07:06.

[7] See Penal Code of 2012

[8] See: Provisional Criminal Code, priill 6, 2004

[9] UNMIK Regulation, No. $1999 \mid 3,1999$

[10] The annual report of the Kosovo Customs Service, the year 2005, 2006 and 2010

[11] See: Law of Tax Administration of Kosovo

[12] Temporary Customs Code of Kosovo of 2004, (Regulation 2004/1

[13] See UNMIK Regulation no. 2005/32

[14] See Annual Reports of the Customs Service from 2005 until now

[15] See newspaper "Kosova Sot" dated March 8, 2006, no. 2316

[16] See Customs and Excise Code of Kosovo, no. 03 | L109

[17] See UNMIK Regulation, 2005/11 